\title{
Geophysics for urban mining and the first surveys in Denmark: rationale, field activity and preliminary results
}

\author{
Alessandro Sandrin ${ }^{1}$, Aleksandar Maricak², Björn H. Heincke'1, Rune J. Clausen', \\ Lars Nielsen², Jakob K. Keiding ${ }^{1}$ \\ ${ }^{1}$ Centre for Minerals and Materials (MiMa), Geological Survey of Denmark and Greenland, Copenhagen, Denmark. ${ }^{2}$ Department of Geosciences and \\ Natural Resource Management, University of Copenhagen, Copenhagen, Denmark
}

\begin{abstract}
Geophysical methods have been widely used in recent decades to investigate and monitor landfill sites for environmental purposes. With the advent of the circular economy, waste contained in old landfills may be considered a resource that can be developed. Since the content of old landfills is largely unknown, the occurrence and quantity of valuable materials must be investigated before embarking on any development activity. Two landfills on Sjælland, Denmark (located at Hvalsø and Avedøre) were selected for a pilot study to characterise their content. At both locations, a set of geophysical surveys is underway. Here, we present the data obtained from magnetic and 2D seismic refraction surveys. Magnetic data show various anomalies that can be interpreted as caused by iron-rich waste. At both sites, the landfill material results in generally low P-wave velocity $(<400 \mathrm{~m} / \mathrm{s})$, lower than those obtained for Quaternary sediments at Avedøre. The seismic velocities appear to increase in the presence of metals or by compaction with depth (>550 m/s). We propose that seismic refraction can thus define the bottom of the landfill and possibly its internal structure, especially when combined with other methods.
\end{abstract}

\section{Introduction}

Societies around the world are increasingly looking at renewable energy and recycling of materials in response to a changing global economy and environmental challenges. Within the field of 'Circular Economy', landfill mining has gained momentum in recent years (e.g. Wagner \& Raymond 2015, Kieckhäfer et al. 2017, Puthussery et al. 2017). Recycling materials from existing landfills may seem straightforward; nevertheless, the economic value of commodities hidden in the waste should be carefully evaluated before they can be exploited. To determine the occurrence and potential quantity of recyclable materials in a landfill, non-invasive methods are preferred (Green et al. 1999; Cardarelli \& Di Filippo 2004; Balia \& Littarru 2010; Boudreault et al. 2010; Belghazal et al. 2013; Dumont et al. 2017; Di Maio et al. 2018). Digging or drilling into landfills may be expensive and environmentally hazardous. For this reason, we chose geophysical methods to investigate two selected landfills on Sjælland, Denmark (located at Hvalsø and Avedøre; Fig. 1). To our knowledge, these are the first such surveys of landfills in Denmark. In this article, we briefly explain the rationale behind the project and its contribution towards
*Correspondence: alsa@geus.dk

Received: 23 Jan 2020

Accepted: 15 Apr 2020

Published: 02 July 2020

Keywords: geophysics, urban mining circular economy, landfill, Denmark

Abbreviations:

RMS: Root Mean Square

SIRT: Simultaneous Iterative Reconstruction Technique

GEUS Bulletin is an open access, peerreviewed journal published by the Geological Survey of Denmark and Greenland (GEUS). This article is distributed under a CC-BY 4.0 licence, permitting free redistribution, and reproduction for any purpose, even commercial, provided proper citation of the original work. Author(s) retain copyright.

Edited by: Catherine Jex (GEUS)

Reviewed by: David Caterina (Université de Liège, Belgium), Philip Carpenter (Northern Illinois University, USA)

Author contributions: See page 6

Funding statement: See page 6

Competing interests: None declared

Additional files: None provided 


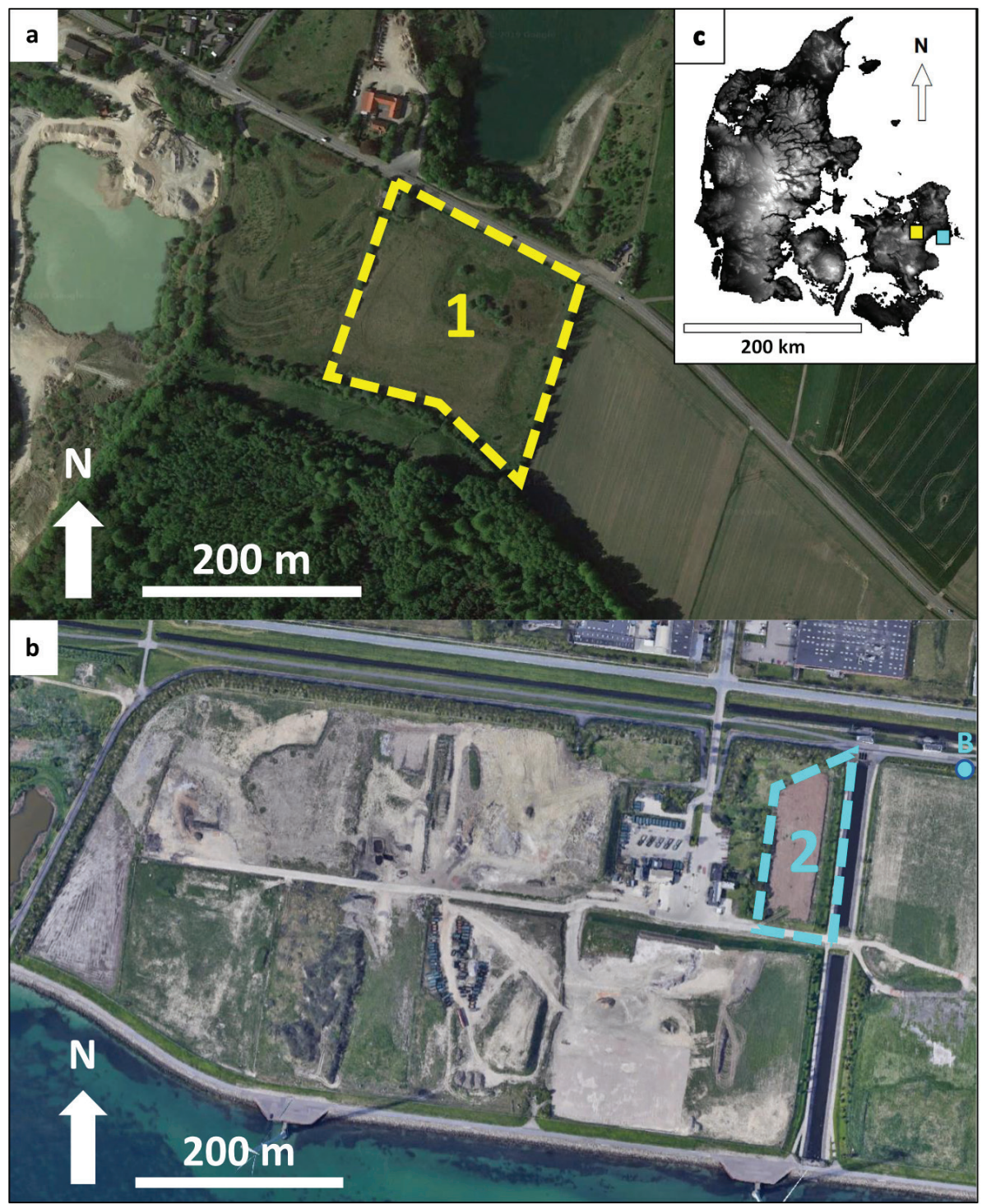

Fig. 1 Landfill sites selected for this study. a: Hvalsø (1 shows the area investigated), b: Avedøre (2 shows the area investigated; $B$ marks the location of an existing borehole), c: Location of the two landfills in Denmark (digital elevation shown in grey shading). The landfill in Hvalsø is composed of various kinds of household waste including metallic objects. The area was remediated and covered with c. $2 \mathrm{~m}$ of soil. In Avedøre, the waste is at the surface and very heterogeneous in character, consisting of wood, plastic, metal and rubber.

a sustainable economy. We describe the field activities at both sites and present the first results from magnetic and 2D seismic refraction surveys of the landfills.

\section{Rationale behind landfill mining}

Raw materials are an essential part of our modern society and there is a growing demand for mineral raw materials in Europe and the rest of the world. This increasing demand raises growing concerns regarding the availability of these resources. In addition to supply risk and resource depletion, our large consumption of resources results in pollution and excessive land use, increasingly jeopardising Earth's life-support systems (Jackson 2009; WWF 2014). To address these issues, and related sustainability needs, the circular economy has become an increasingly popular concept, which aims to eliminate waste and continual use of resources.

Landfills have historically been considered a practical and cost-efficient method for final storage of waste.
However, landfills represent a potential environmental hazard and suboptimal use of resources. The EU is estimated to contain up to 500000 landfills Jones et al. 2013) and although measures have been taken to increase recycling and waste disposal by incineration, $40 \%$ of waste in the EU-27 (the 27 member states of the EU) is still landfilled (Blumenthal 2011). Therefore, landfills continue to be a significant leakage in the circular economy.

Landfill mining refers to the excavation, processing, treatment and recovery of deposited materials situated in informal waste dumps or in structured landfills (Savage et al. 1993). The concept was introduced in the early 1990s and in most cases, it was limited to extraction of methane or for land reclamation. Landfill mining is now being further developed with a greater focus on resource recovery of raw materials. At first glance, landfill mining seems an ideal solution that combines remediation, land reclamation and extraction of raw materials, 
but it has not been broadly implemented. One of the main challenges is the often-low economic performance of landfill mines (e.g. Frändegård et al. 2015; Laner et al. 2019; Clausen \& Kalvig 2020). Prospecting for the most profitable landfills is an important incentive to recognise the feasibility of landfill mining (Krook et al. 2012).

\section{Field work and methods}

The first site is an old landfill in Hvalsø, Sjælland,

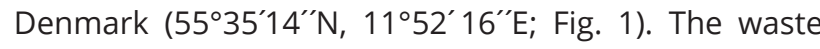
was dumped in an abandoned gravel pit between 1980 and 1985 (Roskilde Amt Teknisk Forvaltning 2003). The site was remediated and covered with soil and a number of wells currently produce biogenic gas from within the landfill (Biorem 2016). Documentation on the quantity and quality of the various types of waste is limited. However, personal and anecdotal information indicate the likely presence of metals in some parts of the landfill. Their exact location and amount are unknown.

The second site is located in Avedøre, SW of Copen-

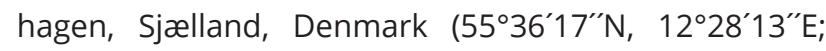
Fig. 1) and is an active landfill. The waste has not been buried, and is therefore still observable at the surface. The waste extends to $c .5 \mathrm{~m}$ depth, with a $20 \mathrm{~cm}$ gravel layer at the base for drainage. Below the gravel, c. 10-13 $\mathrm{m}$ of glacial soil lies directly above carbonates of the Chalk Group (Borerapport DGU 208. 3888, GEUS 1999). The waste is shredder residue of household origin with variable content of plastic, metals, wood and rubber (AV Miljø, personal communication 2019).

Magnetic surveys were conducted to define areas with high magnetic anomalies, likely related to the presence of Fe-bearing waste (Marchetti et al. 2013). The magnetic data were acquired using a Geometrics G-858 Magmapper instrument, with two caesium vapour sensors. A differential GPS positioning system was attached to the operator, who walked the entire area in straight lines whenever possible. Magnetic data were processed, reduced-to-the-pole and mapped using Geosoft ${ }^{\circledR}$ software.

We conducted 2D seismic refraction surveys to delineate the depth to Fe-bearing waste at both sites, assuming that P-wave velocities would increase in Fe-bearing waste compared to the surrounding waste (e.g. Lanz et al. 1998; De laco et al. 2003). Surveys were conducted along a 115-m long transect. A single Geode seismic recorder with 24 channels was used and geophones were deployed with $5 \mathrm{~m}$ spacing. The seismic source for the survey was a hammer hitting a plate coupled to the ground (four stacks). The distance between shots was $2.5 \mathrm{~m}$ at Hvalsø, and $5 \mathrm{~m}$ at Avedøre. For each shot, pre-processing of the data, manual picking of the first-arrival travel times and tomographic inversion were performed using the software package ReflexW ${ }^{\circledR}$ by Sandmaier Geophysical Research (Sandmeier 2014). Two-dimensional first-arrival travel-time tomography is based on an iterative non-linear deterministic inversion and uses rectangular cells for both forward modelling and inversion (Sandmeier 2014). In the forward modelling, a finite-difference approximation of the eikonal equation is used to calculate the travel-time field for the ray tracing. Determination of model updates relies on an iterative SIRT algorithm (Simultaneous Iterative Reconstruction Technique; Sandmeier 2014).

\section{Preliminary results and discussion}

\section{Magnetic surveys}

Magnetic data in both sites show great variability (47 000-56 $000 \mathrm{nT}$ ), indicating that Fe-content is dispersed heterogeneously throughout the waste. At Hvalsø, a significant local magnetic anomaly was detected in the western part of the landfill (white arrow in Fig. 2a). The strong anomalies detected in the southern part of the site are likely produced by nearby manmade structures (e.g. high voltage lines and pylons, Fig. 2a). At Avedøre, the magnetic anomalies do not seem to indicate such local enrichment in Fe-bearing materials. Rather a more uniform distribution is observed, with higher values (up to $55000 \mathrm{nT}$ ) at the east and lower values (down to $48000 \mathrm{nT}$ ) at the west of the site (Fig. 2b). Lower total magnetic field values are observed outside the landfill.

\section{D seismic refraction surveys}

The first-arrival travel times were used for the modelling of the data (Figs 3a, b, c). A starting model with a velocity gradient of $350 \mathrm{~m} / \mathrm{s}$ at the surface, continuously increasing with depth, was created (Fig. 3d). The final tomographic model is shown in Fig. 3e. Ray-tracing diagrams calculated for the given velocity field (Fig. 3f) show the sub-surface coverage provided by the first-arrival travel times.

For the seismic refraction data recorded at Avedøre, the same approach was used. First, the seismic data for each shot were loaded in ReflexW, and then manual picking of the first arrivals was conducted. Band-pass filters and various scaling parameters were applied to allow a reliable interpretation of the first breaks (Figs 4a, b, c). A simple one-layer 2D starting model was created with a $250 \mathrm{~m} / \mathrm{s}$ P-wave velocity at the surface and increasing with depth (Fig. 4d). Various tests were carried out, and in this article only one final model is presented (Fig. 4e). The tomographic inversion shows reasonable root mean square (RMS) values (c. $12 \mathrm{~ms}-$ comparable to the picking uncertainty), especially at far offsets. Figure $4 \mathrm{f}$ displays the ray coverage obtained 

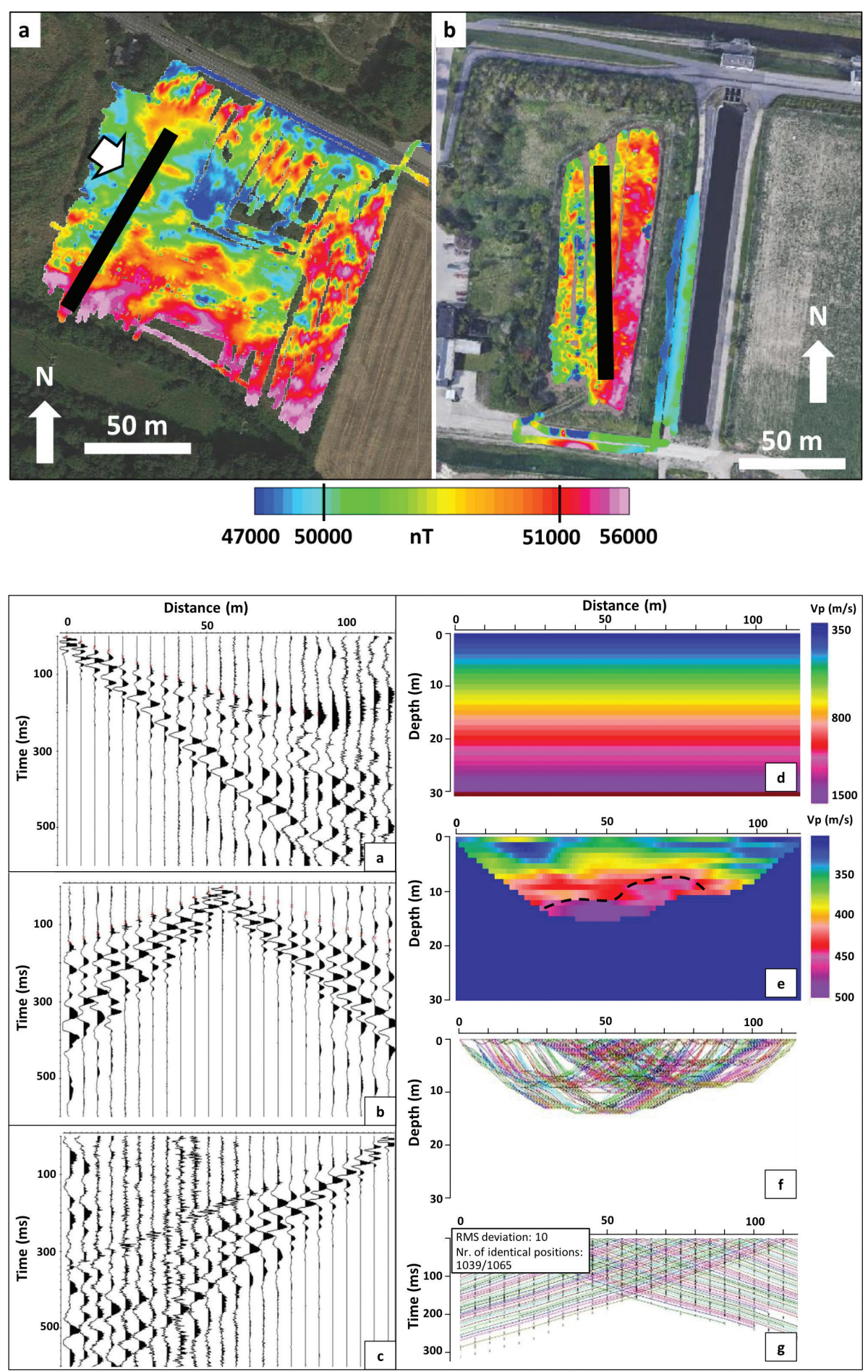

Fig. 2 Total magnetic field maps for landfill sites. a: Hvalsø, b: Avedøre. For reference, the total magnetic field in Copenhagen is 50360 nT. Seismic lines are shown in black.
Fig. 3 Two-dimensional seismic refraction data at Hvalsø. $\mathbf{a}, \mathbf{b}$ and c: data from three selected shots. $\mathbf{d}$ : starting model. e: final P-wave velocity field $(V p)$ obtained from tomographic inversion. The black hatched line marks the top of the Fe-bearing waste. f: ray coverage. g: comparison between calculated (dots) and observed (lines) first-arrival travel times. RMS: root mean square. and Fig. 4g compares the measured and calculated travel times. The velocity field obtained from seismic tomography is in agreement with the lithological log from a nearby borehole (Fig. 4e), which records c. 13 $\mathrm{m}$ of glacial soil overlying Cretaceous carbonates of the Chalk Group. The seismic velocities of the waste (uppermost $5 \mathrm{~m}$ in Fig. 4e) are in the range $250-320 \mathrm{~m} / \mathrm{s}$. The P-wave velocity increases to $>350 \mathrm{~m} / \mathrm{s}$ at c. $5 \mathrm{~m}$ depth (red hatched line in Fig. 4e). At c. 18-20 m below the surface, the velocity appears to exceed $800 \mathrm{~m} / \mathrm{s}$.
Seismic velocity distributions from both landfills indicate velocities of $250-400 \mathrm{~m} / \mathrm{s}$ for non-compacted waste (0-8 m burial depth) of mixed origin. Similar velocities were obtained for landfills in Switzerland (300-800 m/s; Lanz et al. 1998; De laco et al. 2003) and USA (350-550 m/s; Carpenter et al. 2013). Konstantaki et al. (2016) obtained particularly low P-wave velocities (150-200 m/s) in a landfill in the Netherlands, and attributed these to the presence of biogas (which could be the case at Hvalsø). 


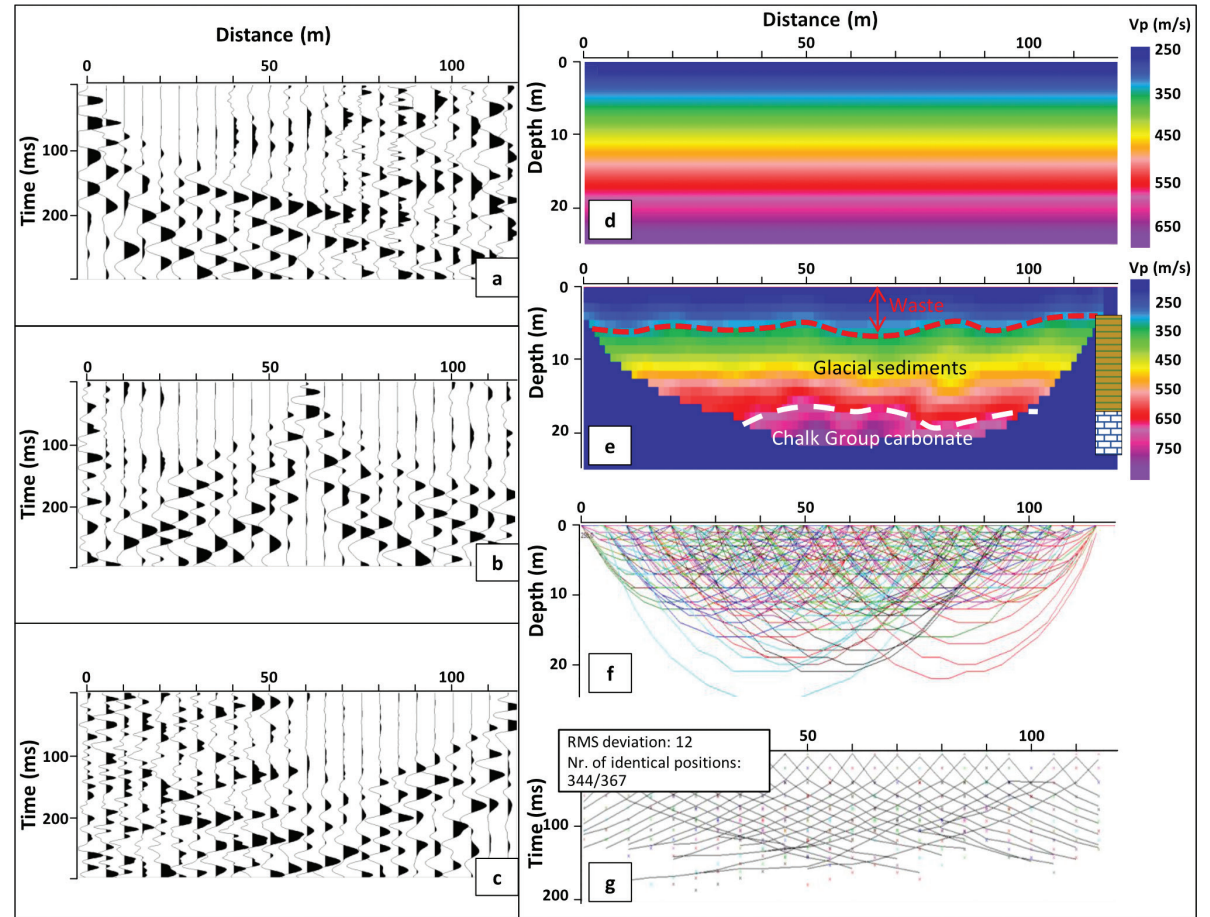

Fig. 4 Two-dimensional seismic refraction data at Avedøre. $\mathbf{a}, \mathbf{b}$ and c: data from three selected shots. d: starting model. e: final P-wave velocity $(V p)$ field obtained from tomographic inversion. The red hatched line marks the interface between waste and glacial soil, white the hatched line marks the top of Chalk. A simplified lithological log of a nearby borehole is shown on the right (light brown shading: glacial sediments, white: carbonates). f: ray coverage. g: comparison between calculated (dots) and observed (lines) first-arrival travel times. RMS: root mean square.
Waste-containing metals are expected to show relatively high $\mathrm{P}$-wave velocities. If the surrounding waste has a velocity in the order of $300 \mathrm{~m} / \mathrm{s}$ and with velocities of metals higher than $3000 \mathrm{~m} / \mathrm{s}$ (Salisbury et al. 1996; Reichmann \& Jacobsen 2004; Nourani et al. 2017), then a mixed volume of the two could have velocities in the order 500-600 m/s - depending upon the amount and connectivity of the metals.

At Avedøre (Fig. 4), velocities of $800-900 \mathrm{~m} / \mathrm{s}$ in the deeper and central parts of the profile can be attributed to the presence of 'fast' chalk lithologies, which often have P-wave velocities $>2000 \mathrm{~m} / \mathrm{s}$ (Nielsen et al. 2011). Here, the ray coverage at depth is not optimal, thus these velocity estimates have large uncertainties. Moreover, the erosion and weathering of the uppermost chalk during glaciations might have led to decreased seismic velocities. Considering these two factors, we can only conclude that the chalk at Avedøre has P-wave velocities in excess of $800 \mathrm{~m} / \mathrm{s}$.

\section{Conclusions and further work}

Preliminary results for two test sites in Denmark indicate waste with P-wave velocities between 250 and $450 \mathrm{~m} / \mathrm{s}$ - comparable to other lose sediments that have not undergone intense compaction. The presence of metals within the waste, however, increases the seismic velocity to values higher than $500 \mathrm{~m} / \mathrm{s}$. The waste appears to be more magnetic than the surrounding glacial soil, with higher values corresponding to areas of high P-wave velocities. The analysis of seismic data alone can support the definition of the landfill base and provide useful information on waste properties, whereas the magnetic survey seems promising for delimiting the deposits horizontal extent, mapping internal heterogeneity and identification of iron-rich zones. Integration with additional geophysical data is required for a more comprehensive characterisation and more detailed site delimitation. For example, geoelectric data can now be modelled to constrain the 3D inversion of the magnetic data at Hvalsø and Avedøre. Further magnetic susceptibility measurements directly on the waste at Avedøre, will also better constrain the modelling of the magnetic field data here.

\section{Acknowledgements}

The authors thank the Department of Geosciences and Natural Resource Management (IGN) at the University of Copenhagen for providing the geophysical instruments. Peer Jørgensen and Mia Benner from IGN are thanked for the help provided in the field. Per Kalvig from Geological Survey of Denmark and Greenland (GEUS) is thanked for discussions and comments on an earlier version of the manuscript. Region Sjælland and AV Miljø are acknowledged for making the sites available and for providing key information on the landfills. Suggestions by the two reviewers helped to improve the original manuscript.

\section{Additional information}

Funding statement

The study was funded by Centre for Minerals and Materials (MiMa) and the Geological Survey of Denmark and Greenland (GEUS). 


\section{Author contributions}

AS: fieldwork, project planning, data analysis, lead scientist. AM: seismic acquisition and processing in Hvalsø. $\mathrm{BHH}$ : supported data modelling. RJC: supported data acquisition. LN: supported data modelling. JKK: writing of the circular economy section and team leader.

\section{References}

Balia, R. \& Littarru, B. 2010: Geophysical experiments for the pre-reclamation assessment of industrial and municipal waste landfills. Journal Geophysical Engineering 7, 64-74. https://doi.org/10.1088/ 1742-2132/7/1/006

Belghazal, H. et al. 2013: Geophysical surveys for the characterization of landfills. International Journal of Innovation and Applied Sciences 4, 254-263.

Biorem. 2016: National network of test sites. https://www.danishsoil.org/ testsites/projekt.php?id=173 (accessed 2019)

Blumenthal, K. 2011: Generation and treatment of municipal waste. Eurostat (European Commission), Luxembourg. KS-SF-11-031-EN-C. https://op.europa.eu/s/n3Qi

Boudreault, J.P. et al. 2010: Geophysical characterization of contaminated urban fills. Engineering Geology 116, 196-206. https://doi. org/10.1016/j.enggeo.2010.09.002

Cardarelli, E. \& Di Filippo, G. 2004: Integrated geophysical surveys on waste dumps: evaluation of physical parameters to characterize an urban waste dump (four case studies in Italy). Waste Management Research 22, 390-402. https://doi.org/10.1177/0734242x04046042

Carpenter, P.J., Reddy, K.R. \& Thompson, M.D. 2013: Seismic imaging of a leachate-recirculation landfill: spatial changes in dynamic properties of municipal solid waste. Journal of Hazardous, Toxic, and Radioactive Waste 17, 331-341. https://doi.org/10.1061/(asce)hz.2153-5515.0000175

De laco, R. et al. 2003: A combined seismic reflection and refraction study of a landfill and its host sediments. Journal of Applied Geophysics 52, 139-156. https://doi.org/10.1016/s0926-9851(02)00255-0

Di Maio, R. et al. 2018: 3D geophysical imaging for site-specific characterization plan of an old landfill. Waste Management 76, 629-642. https://doi.org/10.1016/j.wasman.2018.03.004

Dumont, G. et al. 2017: Assessment of multiple geophysical techniques for the characterization of municipal waste deposit sites. Journal Applied Geophysics 145, 74-83. https://doi.org/10.1016/j.jappgeo.2017.07.013

Frändegård, P., Krook, J. \& Svensson, N. 2015: Integrating remediation and resource recovery: on the economic conditions of landfill mining. Waste Management 42, 137-147. https://doi.org/10.1016/j.wasman.2015.04.008

GEUS Borerapport DGU 208. 3888. 1999: In Danish. Available upon request: https://www.geus.dk/produkter-ydelser-og-faciliteter/data-og-kort/ national-boringsdatabase-jupiter/

Green, A. et al. 1999: A template for geophysical investigations of small landfills. The Leading Edge 18, 248-254. https://doi.org/10.1190/1.1438264

Jackson, T. 2009: Prosperity without growth. Economics for a finite planet. 288 pp. London: Routledge. https://doi.org/10.4324/9781849774338

Jones, P.T. et al. 2013: Enhanced landfill mining in view of multiple resource recovery: a critical review. Journal of Cleaner Production 55, 45-55. https://doi.org/10.1016/j.jclepro.2012.05.021

Kieckhäfer, K., Breitenstein, A. \& Spengler, T.S. 2017: Material flow-based economic assessment of landfill mining processes. Waste Management 60, 748-764. https://doi.org/10.1016/j.wasman.2016.06.012
Konstantaki, L.A. et al. 2016: Wet and gassy zones in a municipal landfill from P- and S-wave velocity fields. Geophysics 81, 75-86. https://doi. org/10.1190/geo2015-0581.1

Krook, J., Svensson, N. \& Eklund, M. 2012: Landfill mining: a critical review of two decades of research. Waste Management 32, 513-520. https:// doi.org/10.1016/j.wasman.2011.10.015

Laner, D. et al. 2019: Systematic assessment of critical factors for the economic performance of landfill mining in Europe: what drives the economy of landfill mining? Waste Management 95, 674-686. https:// doi.org/10.1016/j.wasman.2019.07.007

Lanz, E., Maurer, H. \& Green, A. G. 1998: Refraction tomography over a buried waste disposal site. Geophysics 63, 1414-1433. https://doi. org/10.1190/1.1444443

Marchetti, M., Sapia, V. \& Settimi, A. 2013: Magnetic anomalies of steel drums: a review of the literature and research results of the IGNV. Annals of Geophysics 56, R0108. https://doi.org/10.4401/ag-6201

Nielsen, L. Boldreel, L.O., Hansen, T.M., Lykke-Andersen, H., Stemmerik, L., Surlyk, F. \& Thybo, Het al. 2011: Integrated seismic analysis of the Chalk Group in eastern Denmark - implications for estimates of maximum palaeo-burial in southwest Scandinavia. Tectonophysics 511, 14-26. https://doi.org/10.1016/j.tecto.2011.08.010

Nourani, M.H., Moghadder, M.T. \& Safari, M. 2017: Classification and assessment of rock mass parameters in Choghart iron mine using P-wave velocity. Journal of Rock Mechanics and Geotechnical Engineering 9, 318-328. https://doi.org/10.1016/j.jrmge.2016.11.006

Puthussery, J.V., Kumar, R. \& Garg, A. 2017: Evaluation of recycled concrete aggregates for their suitability in construction activities: an experimental study. Waste Management 60, 270-276. https://doi. org/10.1016/j.wasman.2016.06.008

Reichmann, H.J. \& Jacobsen, S.D. 2004: High-pressure elasticity of a natural magnetite crystal. American Mineralogist 89, 1061-1066. https:// doi.org/10.2138/am-2004-0718

Roskilde Amt Teknisk Forvaltning 2003: Rapport Historisk redegørelse fyldpladser. Lokalitet nr. 257.001, metr. nr. 4al, 8g og 8h, Kirke Hvalsø By, Kirke Hvalsø, Hvalsø Kommune. 16 pp. In Danish. https:// www.danishsoil.org/media/test_sites/7/documents/Historisk\%20redeg\%C3\%B8relse2.pdf (accessed 2019)

Rune J. Clausen, R.J. \& Kalvig, P. MiMa rapport 2020/2. Muligheder og udfordringer for landfill mining i Danmark. ISBN 978-87-7871-536-4. http://mima.geus.dk/udgivelser/landfill-mining-2020/

Salisbury, M.H., Milkereit, B. \& Bleeker, W: 1996: Seismic imaging of massive sulfide deposits; Part I, Rock properties. Economic Geology 91, 821-828. https://doi.org/10.2113/gsecongeo.91.5.821

Sandmeier, K.J. 2014: ReflexW - Version 9.0 (User guide), pp. 341. Sandmeier Geophysical Research, Karlsruhe, Germany. https:// www.sandmeier-geo.de/Download/reflexw_manual_a4.pdf (accessed 2019)

Savage, G.M., Golueke, C.G. \& von Stein, E.L. 1993: Landfill mining: past and present. Biocycle 34, 58-61.

Wagner, T.P. \& Raymond, T. 2015: Landfill mining: case study of a successful metals recovery project. Waste Management 45, 448-457. https://doi.org/10.1016/j.wasman.2015.06.034

WWF. 2014: Living Planet Report 2014: species and spaces, people and places. World Wide Fund for Nature (WWF), Switzerland. https://www.worldwildlife.org/pages/living-planet-report-2014 (accessed 2019) 